\title{
A korkorrigált fejkvóta (kapitáció) a háziorvosi (alapellátási) finanszírozás alapja
}

\author{
Balogh Sándor dr. \\ Pécsi Tudományegyetem, Általános Orvostudományi Kar, Alapellátási Intézet, Családorvosi Tanszék, Pécs
}

\begin{abstract}
Az alapellátás terén olyan strukturális változtatás szükséges, amely nem teljes rendszerében változtatja meg az egészségügyi alapellátást, hanem lehetôvé teszi, hogy a rosszabbul ellátott területeken - elsősorban kistérségi szinten - lehetővé váljék más gyakorlatok alkalmazása. Az erőforrások koncentrálása, az egészségügy finanszírozása kihívást és fejtörést okoz a politikusok és szakmapolitikus számára. Az 1990-es évek kezdetén, a rendszerváltás idején, az egészségügy átalakítása az alapellátással kezdődött. A kezdet a házi/családorvoslás volt, a finanszírozás gerincét a szabad orvosválasztásra alapozott korkorrigált fejkvóta képezte. A biztosítói juttatás ezzel együtt vegyes rendszerü lett. Ezt sok pró és kontra vélemény kísérte és kíséri jelenleg is, de az alapgondolat kiállta a próbáját: az európai jellemzőket és a magyar helyzetet áttekintve, a háziorvosi tételes betegforgalmi jelentések adatai alapján és az ezt megelőző években történt kutatások eredményeit elemezve igazolja a kapitációalapú finanszírozás helyességét, és vélelmezi, hogy e módszer, mint alap, egyszerú, manipulálhatatlan, kevés terhet ró a szolgáltatóra és a biztosítóra, és kis költségekkel jár. A realitásokra is figyelemmel végső soron az ellátás optimalizálását eredményezheti.
\end{abstract}

Orv Hetil. 2019; 160(27): 1057-1063.

Kulcsszavak: kapitáció, rizikó/kor korrigált fejkvóta, tételes betegforgalmi jelentés, fee for service, társadalombiztosítási azonosító jel (taj), életkorhoz kötött morbiditás, GP (általános orvos)

\section{Risk adjusted capitation is the basis for general practitioners' renumeration}

The health care renumeration poses a great challenge for both politicians and policymakers. During the beginning of the 1990s, following the end of communism in Hungary, the reform of health care began with the introduction of the primary health care (PHC), specifically with general practitioner (GPP)/family medicine (FM) care. The basis of the renumeration was the age-adjusted capitation built upon the free choice of doctors, while social security renumeration was built on a mixed system. Several pros and cons have been highlighted, but the underlying principle has proved to be simple and effective. Comparison of the European and Hungarian characteristics, analysis of data in the present patient care report as well as in the years preceding the release of the aforementioned document, these confirm that the method of capitation-based remuneration is a fundamental, easy, and unmanipulable method. It places minimal weight on social security and comes with little costs.

Keywords: capitation, risk adjusted capitation, patient care report, social security number, fee for service, age-related morbidity, GP (general practitioner)

Balogh S. [Risk adjusted capitation is the basis for general practitioners' renumeration]. Orv Hetil. 2019; 160(27): 1057-1063.

(Beérkezett: 2018. december 12.; elfogadva: 2018. december 20.)

\section{Rövidítések}

$\mathrm{BNO}=$ betegségek nemzetközi osztályozása; $\mathrm{FM}=($ family medicine) családorvoslás; GP = (general practitioner) általános orvos, orvoslás; ISZB = ischaemiás szívbetegség; NEAK =
Nemzeti Egészségbiztosítási Alapkezelő; PHC = (primary health care) egészségügyi alapellátás; taj = társadalombiztosítási azonosító jel; TEK = területi ellátási kötelezettség 
Az alapellátás területén indokolt a feladatellátásra épülő struktúraváltás; a múködő és hatékony szolgáltatások együttmúködését az integrált szervezeti forma, illetve a kistérségi szolgáltatások kialakítása, múködtetése és monitorozása segítheti. A nemzetközi példák és ajánlások alapján a kis lélekszámú települések esetében a kistérségi egészségközpontok kialakítása képes a leginkább megfelelni a lakosság igényeinek, az ellátórendszer lehetőségeinek és az ellátásért felelős önkormányzatok elvárásainak.

$\mathrm{Az}$ alapellátás pontos feladatainak és szakma szerinti meghatározását a 2015. évi CXXIII. törvény tartalmazza [1]. Az alapellátás meghatározó része a háziorvosi ellátás, melynek múködése minden európai országban kihat az egészségügyi ellátórendszerre [2]. Ma a háziorvosi 66 milliós orvos-beteg találkozásnak 13\%-a valamilyen kompetenciahiány vagy elö́rás, adminisztratív ok miatt következik be, a dobogósok: 14,5\% hypertonia [1], 13,4\% légúti megbetegedés, 12,5\% mozgásszervi betegség [3].

\section{Öregedő háziorvos-társadalom}

A háziorvosok átlagéletkora évről évre növekszik, a 2009. év végén 54,5 év volt; a 60 év feletti háziorvosok aránya 17 év alatt 10,3\%-ról 27,4\%-ra, az 50 év felettiek aránya 37\%-ról 66,3\%-ra nőtt, azaz minden három háziorvosból kettő idősebb 50 évesnél, és várhatóan 15 éven belül nyugállományba történő vonulása időszerü. Ez 15 éven belül várhatóan 3138 háziorvos utánpótlását igényli; 2018-ra a helyzet romlása mérséklődött, de sürgős intervenciót igénylővé vált [4].

\section{Az alapellátás finanszírozása Európában}

Az egészségügyi rendszerek, ezen belül is az alapellátás finanszírozása kisebb-nagyobb eltéréseket mutat Európában. Számos hasonló, de arányaiban eltérő finanszírozástechnikát alkalmaznak [5].

Az 1. táblázat adatai szerint a finanszírozás gyakori eleme a korrigált fejkvóta, amelynek részaránya az elmúlt két évtizedben az európai országok finanszírozásában nőtt, meghatározó mértékűvé vált $[6,7]$. A XX. század végén, amikor a keleti blokk országaiban az egészségügyben is bekövetkezett a rendszerváltás, 32 európai ország finanszírozása közül 6-ban alkalmazták a kapitációt, 15-ben a bérfizetést és 11-ben a 'fee for service'-t. A XXI. század első évtizedére ez a számarány megváltozott - 19 országból 15-ben $(80 \%)$ a finanszírozás kapitációalapú lett, és az összfinanszírozáshoz arányítva 30-88\%-os részarányt jelentett. A volt szocialista országok közül (7 ország adatai) valamennyiben alkalmazták a korkorrigált fejkvótát.

Gress és mtsai számos különböző fizetési rendszert találtak Európában, részleteiben elemezték az egyes rendszerek által nyújtott ösztönzőket. Azt állították azonban, hogy a fizetési rendszerek túlzott figyelmet kapnak, nem azért, mert erôs irányítású mechanizmusok, hanem azért, mert manipulálhatók. Hangsúlyozták, hogy a há- ziorvosoknak nemcsak pénzügyi ösztönzőket kell figyelembe venniük, de azokon felül kötelező iránymutatásokat, szakmai szabványokat és etikai korlátokat is, amelyek szintén befolyásolják a GP viselkedését, akár szakmai tevékenységét. Mivel az általános módszerek az egész egészségügyi rendszer részei, az ösztönzőket nem lehet elszigetelten, önmagukban értékelni. A kísérleti módszerek eredményei megmutatták egy adott ország gyakorlatát. Megállapították, hogy nem lehet mechanikusan másolni az egyik ország módszereit más országok tekintetében, például a különböző egészségügyi rendszerek jellemzői miatt [8].

Az alapellátásban a vegyes szolgáltatói finanszírozási mechanizmusok tendenciája múködik: számos országban a kockázatkiigazított fejkvótát kombinálják szolgáltatásalapú díjazással. Az utóbbi időben több országban teljesítményalapú programokat is bevezettek, az ellátás minőségének fejlesztéséért. A pénzügyi ösztönzők ugyanakkor önmagukban nem valószínű, hogy elegendőek a szolgáltatók magatartásának megfelelő irányba terelésére, ezért ezeket megfelelő eszközökkel kell társítani, beleértve a monitoringot és a visszacsatolást [9].

Európában három megkülönböztethető fizetési rendszert alkalmaznak a család/házi/általános orvosok számára:

- 'Fee for service' finanszírozás: ebben a rendszerben a finanszírozás közvetlenül kapcsolódik az elvégzett munkához. Ebben a háziorvosok kevesebb feladatot delegálnak más szolgáltatóknak, más finanszírozási/ ellátási szintekre. A költségek megóvása a GP-szolgáltatás szintjén problémákat okozhat (felülről zárt kassza). Ilyen rendszerekben a biztosítónak vagy az államnak nehéz feladat - a költségnövekedés megakadályozására - költségvetési (elszámolási és finanszírozási) fékek, technikák alkalmazása és múködtetése. A szakorvosi ellátás igénybevételének csökkentése azonban költségmegtakarítást és pénzügyi ösztönzést jelenthet a háziorvosok számára.

- Kapitáció szerinti finanszírozás: a háziorvosok pénzt kapnak egy betegért egy meghatározott időtartamra. A betegeket regisztrálják a GP-listán. A kifizetések alapját jelenthetik az egyenlő hozzáférést biztosító kockázatok, de más ösztönzóket is kell alkalmazni. Ilyen például a kockázati kiigazítás (risk adjustment) magasabb díj folyósításával, az idősek vagy krónikus betegek vagy a hátrányos helyzetűek tekintetében. A háziorvosok a pácienst hajlamosak lehetnek átterelni az ellátás más szintjeire, mivel ez csökkentheti munkaterheiket. Mindennek ellenére ez a megoldás, az alapellátás számára optimális az elsődlegesség a folyamatosság és a prevenció alapelveinek megoldásában.

- Fizetés/alkalmazottak: a háziorvosokat az időegységekért (óradíj) fizetik, függetlenül attól, hogy milyen szolgáltatásokat nyújtanak, és hány beteget látnak el. Ez a rendszer az orvosok és az ellátottak számára egyaránt garantálni kívánja a hozzáférhetőséget. Alulfinanszírozott rendszerekben azonban ez a két funk- 
1. táblázat | Díjazási rendszerek a háziorvosi praxisokban

\begin{tabular}{|c|c|c|c|c|c|}
\hline Ország & $\begin{array}{l}\text { Fejpénz } \\
\text { (kártyapénz) } \\
\text { kockázatkor- } \\
\text { rekcióval }\end{array}$ & $\begin{array}{l}\text { Tételes } \\
\text { teljesítmény- } \\
\text { finanszírozás }\end{array}$ & Fízetés & $\begin{array}{l}\text { Bónusz, } \\
\text { teljesítmény- } \\
\text { díjazás, egyéb } \\
\text { juttatások }\end{array}$ & Különleges finanszírozási jellegzetességek \\
\hline Ausztria $^{*}$ & I & I & & & \\
\hline Ausztria (magán) & & I & & & 57\% magánháziorvosok \\
\hline Belgium & & I & & $\mathrm{I}$ & \\
\hline Bulgária & I & & & I & $\begin{array}{l}\text { Bónusz orvosi nyilvántartás vezetésére és megelőző szolgáltatások } \\
\text { nyújtására }\end{array}$ \\
\hline Csehország & k.k. & I & & & Kor szerinti fejpénz (kártyapénz) \\
\hline Dánia & I & I & & & Tételes teljesítményfinanszírozás $2 / 3$, fejpénz $1 / 3$ \\
\hline Észtország & k.k. & I & & I & $\begin{array}{l}\text { Kor szerinti fejpénz (kártyapénz) 73\%, tételes teljesítményfinanszí- } \\
\text { rozás } 15 \% \text {, alapilletmény } 10 \%\end{array}$ \\
\hline $\begin{array}{l}\text { Finnország* } \\
\text { (1. rendszer) }\end{array}$ & & & I & I & Bónusz a munkaidőn kívüli (ügyeleti) ellátásért \\
\hline $\begin{array}{l}\text { Finnország } \\
(2 . \text { rendszer })\end{array}$ & I & I & I & I & Bónusz a munkaidőn kívüli (ügyeleti) ellátásért \\
\hline Franciaország & & I & & I & Teljesítménydíjazás: önkéntes \\
\hline Németország & & I & & & Finanszírozási plafon \\
\hline Görögország & & I & & & A paraszolvencia (informális díjazás) elterjedt \\
\hline Írország (nyilvános)* & k.k. & I & & & $\begin{array}{l}\text { A fejpénz (kártyapénz) az életkortól és a praxistól való távolságtól } \\
\text { függ }\end{array}$ \\
\hline Írország (magán) & & I & & & \\
\hline Olaszország & I & I & & I & Jutalom a költséghatékonyságért \\
\hline Lettország & k.k. & I & & I & $\begin{array}{l}\text { Kor szerinti fejpénz (kártyapénz), bónusz a teljesítménymutatókért } \\
\text { és az alacsony beutalási rátáért }\end{array}$ \\
\hline Hollandia & k.k. & I & & & $\begin{array}{l}\text { Kor és hátrányos területek szerint korrigált fejpénz (kártyapénz), } \\
\text { munkaidőn túli munka (ügyelet) óradíjban fizetve }\end{array}$ \\
\hline Norvégia & I & I & & & Fejpénz (kártyapénz) a jövedelem $30 \%$ \\
\hline Lengyelország & & & I & & \\
\hline Portugália & & & I & & \\
\hline Románia & k.k. & I & & I & \\
\hline Szlovákia & k.k. & I & & & $\begin{array}{l}\text { Kor szerinti fejpénz (kártyapénz) 85\%, csökkentett díjazás } \\
\text { nagyszámú beteg vagy szolgáltatás esetén (degresszió?) }\end{array}$ \\
\hline Szlovénia & I & I & & & $\begin{array}{l}\text { Fejpénz (kártyapénz) } 50 \% \text {, tételes teljesítményfinanszírozás } 50 \% \text {; } \\
\text { bónusz az alacsony beutalási ráta alapján }\end{array}$ \\
\hline Spanyolország & I & & & I & Életkorra, népsűrűségre és mortalitásra korrigált: 15\% \\
\hline Svédország & & & & I & Megyénként különböző lehet \\
\hline Egyesült Államok & k.k. & & & I & $\begin{array}{l}\text { A fejpénzt (kártyapénzt) számos faktor módosítja, teljesítménydíja- } \\
\text { zás a minőségi mutatók teljesítése esetén }\end{array}$ \\
\hline
\end{tabular}

*Ausztriában, Finnországban és Írországban két díjazási rendszer létezik a háziorvosok számára.

k.k. = kockázatkorrekció; I = igen

ció nem valósul meg. Az alulfinanszírozás ösztönzi az orvosokat, hogy formális ellátásokat nyújtsanak, amelyek akadályozhatják bizonyos betegcsoportok számára a hozzáférést. Fennáll az a helyzet, hogy páciensek továbbutalására az indokoltnál gyakrabban kerül sor, és ez alulkezelést (definitív ellátást) okozhat. Ezekben a rendszerekben a betegek gyakran panaszkodnak az orvosokra.
- Vegyes rendszerek: a kifizetési rendszerek kevert formában fordulnak elő:

- Kapitációs díj jár minden beteg után, és kiegészítő kifizetések bizonyos feladatokhoz társulnak (szolgáltatás díj), ezek célzott kifizetések. Ilyen, amikor a kifizetések előre meghatározott tevékenységhez kapcsolódnak, például védőoltásokhoz, a nagy kockázatú lakosság influenzaátoltottságának százalékos 
arányához. Ha a GP teljesíti a célt, akkor extra kifizetésekhez jut hozzá. Ha nem éri el a célt, további kifizetésekre nem kerül sor. Ezek a funkciójú kifizetések a háziorvosok extra feladataira, szolgáltatásaira is alkalmazhatók. Az utóbbira példa a szlovákiai vastagbélszürés finanszírozása vagy preventív intervenciók elvégzésének külön tételes díjazása.

- Vegyes kifizetés a különböző betegcsoportok számára (például magán- vagy biztosított betegek), biztosítottak/nem biztosítottak, több-biztosítós rendszer esetén.

- Különböző kifizetési rendszerek különböző háziorvosok számára, az egészségügyi rendszeren belül történően, ami a magyar rendszer példái alapján érthető meg jobban, úgymint vegyes praxis, gyermekpraxis, TEK nélküli praxis stb.

- Integrált költségátvezetés: itt a háziorvosok fizetnek a betegek egészségügyi ellátásáért más ellátószinteknek. A rendszert gyakran alapítványként említik. A GP-k jövedelme, az integrált kapitációs díj/ fő vagy /alkalom, a listán szereplő betegek száma szerinti összeg, mely csökkentésre kerül a más szolgáltatóknál igénybe vett szolgáltatások költségével. A célzott ösztönzők az ellátás folytonosságának és átfogó jellegének előmozdítását, az interdiszciplináris koordinációt és az aktív betegség kezelését segítik. Ugyanakkor jelentős kockázatot jelent a betegek másodlagos vagy harmadlagos ellátása költségeinek kockázata [8].

- Betegséggel kapcsolatos finanszírozás. Ebben a rendszerben a GP-k meghatározott betegek számára külön térítést kapnak, azok betegségétől függően (például cukorbetegség), a betegség kezeléséhez számított fix összeget. A finanszírozás magában foglalja a beteg összes egészségügyi kiadását, ideértve a megelőző ellátást és a speciális gondozást is. $\mathrm{Az}$ ellátásban a bizonyítékokon alapuló klinikai iránymutatásokat alkalmazzák [10].

Európában ma az országok többségében vegyes fizetési rendszer van érvényben (1. táblázat), bár gyakran a rendszer egy-egy eleme domináns. Vannak országok, ahol a háziorvosok fizetést kapnak, alkalmazottak: Finnország, Lengyelország, Portugália, Spanyolország és Svédország. Svédország egy részében elsősorban az alkalmazott orvosok dolgoznak, de vannak olyan svéd megyék is, ahol más finanszírozási rendszerek is léteznek, hiszen a svéd egészségügyi rendszer felelőssége a megyék szintjére került. Portugáliában és Lengyelországban egy rendszer létezik fizetéses, alkalmazotti formában. Lengyelországban azonban a GP-k alacsony bérei miatt léteznek informális (szürke zónás) fizetségek, amelyeket a betegek közvetlenül a GP-knek fizetnek a gyorsabb hozzáférésért vagy a jobb minőségü szolgáltatásokért. A portugál orvosok egészségügyi központokban dolgoznak. Ezeket az egészségközpontokat közvetlenül a helyi kormányzati szerv fizeti a valós kiadások alapján. Ez azt jelenti, hogy nincs globális költségellenőrzés. Ausztriában (nyilvántartott háziorvosok), Bulgáriában, Észtországban, Írországban, Olaszországban, Lettországban, Romániában és Angliában a domináns elem mellett további finanszírozási formák múködnek, amelyek leginkább a hatékonyságért vagy bizonyos szolgáltatásokért, például megelőző szolgáltatások elvégzéséért járnak. A szolgáltatások promóciójának kifizetése a teljesítményfizetés formája: ha például bizonyos küszöböt (például egy bizonyos százalékot) az immunizált betegek aránya elér, akkor bónuszt kap a GP. Az országok többségében szolgáltatási díjakat is meghatároznak, így Belgiumban, Dániában, Franciaországban, Németországban, Görögországban és Hollandiában. Más országokban többnyire a kapitáció az alap, mellette bizonyos szolgáltatásokért, például az orvosi nyilvántartások vezetéséért vagy minőségi mutatók eléréséért pluszfinanszírozás jár [11].

Európa összetett helyzetének ismertetése alapján nem tûnik merész megállapításnak, hogy bonyolult, az adott ország sajátosságainak figyelembevételével kell a legoptimálisabb megoldásra törekedni.

Az életkor és a betegségek összefüggésében az ellátás sajátosságait és teljesítményét az eddig említett közleményekben szereplőkön túl több tényező módosíthatja. Ezek mértékének meghatározása, multifaktoriális volta miatt, nehezen és túl bonyolultan mérhető [12-15].

A saját tapasztalat és az irodalmi áttekintés eredményei alapján a következőkben a fejkvóta, a korkorrigált fejkvóta alkalmazásának és dominanciájának indokoltságát mint a szakmai tevékenység legegyszerúbben elszámolható, manipulálhatatlan teljesítményértékét kívánom igazolni.

\section{A vizsgálat célja}

Az alapellátás (háziorvoslás) elmúlt két évtizedének európai eredményeinek ismeretében, korábbi saját munkákban talált eredményekből kiindulva, a ma már folyamatosan rögzített háziorvosi jelentések (tételes betegforgalmi jelentés) és azok feldolgozásai alapján keletkezett adatok ismertetésével és azokból levont következtetésekkel a kapitációalapú finanszírozás dominanciájának igazolása.

\section{Az adatgyújtés köre}

A 2010 és 2016 közötti időszak háziorvosi tételes betegforgalmi, a NEAK által rendelkezésre bocsátott adatai alapján 2010-ben 5108, 2016-ban 5080 felnőtt- (14 év feletti) vagy vegyes praxis megküldött jelentései. Ezek közül kiemelten került vizsgálatra az ellátottak taj szerinti száma, ellátási eseményeik gyakorisága, az ellátás oka és az ellátásban részesülők egyéb (kísérő) betegségei BNO szerint, 10 éves korcsoportos bontásban. 
2. táblázat |Az egyes megbetegedések korcsoportok szerinti előfordulása (\%)

\begin{tabular}{|c|c|c|c|c|c|}
\hline & 14-20 év & 2l-40 év & 41-60 év & 60- év & \\
\hline Diabetes & 0,3 & 6,1 & 38,9 & 54,6 & $100 \%$ \\
\hline Neurózis & 2,9 & 38,6 & 43,6 & 14,9 & $100 \%$ \\
\hline ISZB & 0,3 & 5,3 & 35,6 & 58,9 & $100 \%$ \\
\hline Hypertonia & 0,4 & 7,0 & 39,6 & 52,9 & $100 \%$ \\
\hline Légút & 23,8 & 45,4 & 21,5 & 9,4 & $100 \%$ \\
\hline Csont & 3,7 & 36,4 & 43,0 & 16,9 & $100 \%$ \\
\hline
\end{tabular}

A légúti megbetegedések a 40 év alattiakban gyakori, majd az ettől kezdődő korosztályokban csökkenő mértékű. A szív-ér rendszeri betegségek (ISZB), a hypertonia, a diabetes a 40 feletti korúaknál fokozatosan nőtt [16-18].

3. táblázat |A leggyakoribb betegségi fő́csoportok kor szerinti alakulása (\%)

\begin{tabular}{|c|c|c|c|c|c|}
\hline \multirow{2}{*}{$\begin{array}{l}\text { Betegségi fôcsoportok } \\
\text { (BNO-10) }\end{array}$} & \multicolumn{4}{|c|}{ Korcsoportok (év) } & \multirow[t]{2}{*}{ Összesen } \\
\hline & $16-19$ & $20-39$ & $40-59$ & $60+$ & \\
\hline IV. Endokrin, táplálkozási és anyagcsere-betegségek & 1,5 & 5,1 & 8,1 & 16,5 & 7,7 \\
\hline V. Mentális és viselkedészavarok & 0,4 & 0,7 & 3,5 & 4,7 & 1,8 \\
\hline IX. A keringési rendszer betegségei & 9,9 & 12,8 & 28,2 & 50,8 & 24,5 \\
\hline X. A légzőrrendszer betegségei & 6,6 & 4,9 & 4,8 & 3,1 & 4,8 \\
\hline XI. Az emésztőrendszer betegségei & 1,5 & 1,9 & 3,5 & 5,0 & 3,0 \\
\hline XI. A csont-izom rendszer és kötőszövet betegségei & 5,9 & 7,2 & 18,5 & 28,5 & 14,6 \\
\hline
\end{tabular}

\section{Eredmények}

A korábban, 1984 és 1986 között a praxisanalízis módszerével végzett vizsgálatok - amelyek kézzel kitöltött adatlapok alkalmazásával, kezdetleges informatikai eszközhátterú adatfeldolgozás mellett történtek - megmutatták, hogy 7 körzeti orvosi körzet egyéves betegforgalmi adatai alapján az egyes korcsoportoknak jellemző megbetegedéseik vannak. Ekkor a rendelkezésre álló számítógé- pek nem tették lehetővé a nagyszámú adatból, a taj hiányából az egyes korcsoportok egyes betegeinek orvoshoz fordulási gyakoriságát kalkulálni (2. táblázat) [16-18].

A közel két évtizeddel később a nők egészségét elemző dél-alföldi vizsgálat hasonló tendenciákat mutatott. Érzékelhető különbség volt a légzőszervi megbetegedések tekintetében, illetve magasabb arányban tapasztaltak a 40 év alattiak korcsoportjában keringési rendszerrel kapcsolatos panaszokat (3. táblázat) [19].

4. táblázat |Az orvoshoz fordulók száma a három leggyakoribb betegségcsoportban 2016-ban

\begin{tabular}{|c|c|c|c|c|c|c|c|}
\hline Kor & 18-29 év & 30-39 év & 40-49 év & 50-59 év & 60-69 év & 70-79 év & $80+$ év \\
\hline I. $/ 1$. & Légúti & 1. Légúti & 1. Keringés & 1. Keringés & 1. Keringés & 1. Keringés & 1. Keringés \\
\hline II. & $15072852 \times$ & $12809203 \times$ & $27210036,6 \times$ & $62031709,9 \times$ & $1247512917,7 \times$ & $1215498917,2 \times$ & $8905698 \times$ \\
\hline III. & $50732350 \%$ & $42980744 \%$ & $41116836 \%$ & $62802763 \%$ & $96785681 \%$ & $70337892 \%$ & $41371494 \%$ \\
\hline I. $/ 2$. & eg. áll & 2. eg. áll. & 2. Csont & 2. Endokrin & 2. Endokrin & 2. Endokrin & 2. Endokrin \\
\hline II. & $13403873 \times$ & $1131382,4 \times$ & $18884874,3 \times$ & $34053298,6 \times$ & $682670210.3 \times$ & $550801111 \times$ & $271720311 \times$ \\
\hline III. & $52732352 \%$ & $46228647 \%$ & $43594738 \%$ & $39657740 \%$ & $66242255 \%$ & $48497563 \%$ & $24880256 \%$ \\
\hline I. $/ 3$. & Fertőző & 3. Keringés & 3. Endokrin & 3. Csont & 3. Csont & 3. Csont & 3. Csont \\
\hline II. & $7499562,5 \times$ & $8225024,6 \times$ & $15505175,7 \times$ & $31364086,2 \times$ & $46820207 x$ & $38986578 \times$ & $25176639,3 \times$ \\
\hline III. & $33475833 \%$ & $17712318 \%$ & $27111323 \%$ & $50496651 \%$ & $67649957 \%$ & $47905062 \%$ & $26160762 \%$ \\
\hline
\end{tabular}

I. = a megbetegedések diagnóziscsoport szerinti megnevezése

II. = az I. csoportokban megnevezett diagnózissal való megjelenések száma

II. $\times \quad=$ az adott diagnóziscsoporttal egy ember hányszor keresi fel a háziorvost

III. = az adott diagnóziscsoporttal ellátottak száma (egy ellátotti megjelenéstől függetlenül egyszer)

III.\% = az adott diagnóziscsoport ellátottjai és az összpopuláció \%-ban

1, 2, 3 = az adott diagnóziscsoportnak az ellátottak száma szerinti sorrendje (ellátási gyakoriságának sorrendje) 
A 4. táblázat a 2016-os év háziorvosi tételes betegforgalmi jelentések alapján a három legnagyobb számú ellátást tartalmazza, BNO szerinti betegségcsoportokra és korcsoportokra bontva (a NEAK adatbázisa szerint). A 40 év alatti korcsoportokban jellemzően egyszerű felső légúti, légúti és vélhetően ezek fertőző betegségnek kódolt esetei voltak. A sorrendben második leggyakoribb orvoshoz fordulási okot jelentettek csoportját alkották a 'Z' BNO-kódoltak. A 'Z'-kódok az adminisztratív okokat, azaz elsősorban a nem konkrét betegséggel összefüggő ellátásokat jelentették. Ezek közül kiemelten fontos és a leggyakoribb a fogamzásgátló gyógyszer felírása. A 30 és 39 év közöttiek három leggyakoribb oka közül harmadikként a szív-ér rendszeri panasz, betegség került ellátásra. A 40 éves kort követően a keringési megbetegedések folyamatosan az első pozíciót foglalták el. A második legnagyobb számú megjelenést az endokrin betegségek jelentették, ezek több mint 90\%-a diabetes. E korosztályokban a harmadik helyen a csont-ízületi megbetegedéseket regisztrálták. A 40 év felettieknél az életkor növekedésével minden megbetegedési csoportban növekedett az orvoshoz fordulási gyakoriság, az ellátási igény. A szív-ér rendszeri és diabeteses betegek ellátási igénye a háromszorosára nőtt, illetve az adott lakossági korosztályból ellátásra kerülők mindhárom csoportban növekvő és jelentős százalékot jelentettek. Egy betegségcsoport ellátási gyakorisága markáns különbségeket mutatott az egyes korosztályokban. A különbségek kisebbek voltak a 70 és 79 év közötti korúaknál és a 80 év felettieknél.

Megvizsgálva a 2010., 2012. és 2014. éves tételes betegforgalmi jelentéseket, nem voltak különbségek az egyes évek betegforgalmi adatai között. Ugyanígy, amikor az egyes megbetegedéscsoportok jelentett BNOkódjainak száma került összevetésre, nem volt található eltérés az egyes korcsoportok és a négy év BNO-számai között.

\section{Következtetés}

A magyar egészségügy átalakításának kezdetekor az alapellátással, ezen belül is a háziorvoslással indult meg a szocialista egészségügy európai irányú átalakítása. Az alapvetô finanszírozási elemek máig nem változtak. $\mathrm{Az}$ egyes elemek pénzügyi ráfordításai némileg módosultak, de a kiemelhető új elem a minőségi munkát szándékozott ösztönözni az indikátorrendszer mérésével.

Bármennyire is szakmai elvekre igyekezett ez az új elem támaszkodni, nem tudta beváltani a hozzá füzött reményeket, bár folyamatos szándék volt módosítani. A minőségi indikátormódszer nagy előnye, hogy a háziorvos által nem lehet direkt módon befolyásolni, de ez egyben nagy hátrányává is vált.

Az elmúlt bő évtizedben mind a szolgáltatók, mind a szakmapolitikusok, mind a jogalkotók, mind a finanszírozó folyamatosan keresték a lehetőségeket és tettek különféle javaslatokat a minőségi és teljesítményalapú fi- nanszírozásra. Számos háttérszámítás, projekt és azok eredményei, melyeket a szakterületen dolgozók és intézményi keretekben munkálkodók végeztek, segítették az előkészítést, biztosítottak a megoldáshoz alapokat [2023].

Közben számos európai és itthoni folyamat alapvetően befolyásolta az európai és a magyar egészségügynek, ezen belül is a háziorvoslásnak a helyzetét. Ezek közül nem volt elhanyagolható a mára már némileg konszolidálódott gazdasági válság. Talán még ennél is jelentősebb probléma a szakemberhiány, ezen belül is az orvoshiány. A kedvezőtlen jelenségek nemcsak Magyarországot és Európát, hanem az egész világot érintik. Emellett a gyógyításköltség robbanása jelentős mértékben megnövelte az ellátás költségeit is. Nem lehet nem beszélni arról sem, hogy a társadalom elvárásai, igényei és információs lehetőségei növekvő mértékben eredményezték a klasszikus egészségüggyel a társadalom nem kis részének a szembefordulását. A társadalom, elsősorban a fiatalok elvárása a szolgáltató típusú ellátás igényével jelentkezik, de a klasszikus gyógyítás, amely a szolgálat értékelvén és gyakorlatán áll, nem tud a szolgáltatás gyakorlata és elvárása szerint múködni.

A szolgáltatók által szimpatikusnak tartott 'fee for service'-t mint finanszírozási technikát nem kedvelik a biztosítók (és az állam), mert az elszámolás bonyolult megoldások útján, általában „kozmetikázható” alapon történik, és számos, nemritkán költséges és feszültségeket okozó ellenőrzési rendszer segítségével sem hatékony. Továbbá a költségvetési alapon meghatározott pénzkeret zárt rendszere sem teszi az eljárás alkalmazását lehetővé.

Tekintettel arra, hogy az országok költségvetésében zárt keretek állnak rendelkezésre, a 'fee for service' igen költséges elszámolási rendszer, amely így foglalható öszsze: a biztosítási elszámolási költségek növekedése bizonyíthatja, hogy 1 dollárból hogyan marad csak 80 cent az egészségügyre, és a többi a biztosítónak jut, a rendszer fenntartására fordítódik.

Bármennyire szimpatikus is ez a megoldás az orvostársadalom körében, nem kap elég hangsúlyt a mindennapokban, és hihetetlen adminisztrációs terhet ró az elszámolás miatt az egészségügyi ellátókra.

A jelenlegi helyzetben megfontolandó, hogy a korkorrigált fejkvóta elfogadható és hatékony eleme a finanszírozásnak. Az eredményekben bemutatott számítások igazolják az életkorral összefüggő, az életkorra jellemző megbetegedéseket, amelyek egyben meghatározzák az orvoshoz fordulás indokait és gyakoriságát, valamint a járóbeteg-, vagy a fekvőbeteg-ellátás igénybevételének szükségességét is. Mindezek objektív, alig változó alapjai a teljesítménynek. Amennyiben a képzés, szakképzés és folyamatos továbbképzés, valamint a 'peer review' és szakmai kontroll kellőképpen hatékony, akkor garantált és ellenőrzött a minőség és a szakmai hatékonyság is. Mindazok a kiegészítő finanszírozási elemek, amelyek részei a finanszírozási rendszernek, a korkorrigált fejkvó- 
ta dominanciája mellett alkalmasak a háziorvoslás jelen állapotában a rendszer fenntartására és igazságos finanszírozására.

Anyagi támogatás: A közlemény megírása anyagi támogatásban nem részesült.

A cikk végleges változatát a szerző elolvasta és jóváhagyta.

Érdekeltségek: A szerzőnek nincsenek érdekeltségei.

\section{Irodalom}

[1] Act CXXIII. of 2015 primary health care. [2015. évi CXXIII törvény az egészségügyi alapellátásról.] Magyar Közlöny 2015 102: 17507-17514. [Hungarian]

[2] Starfield B. Is primary care essential? Lancet 1994; 344: 11291133.

[3] Editorial Notice. [Szerkesztőségi közlemény.] Medicus Universalis 2017; 50: 70. [Hungarian]

[4] Publication of Hungarian National Institute of Primary Health Care. [Az Országos Alapellátási Intézet kiadványa.] Országos Alapellátási Intézet, Budapest, 2011. [Hungarian]

[5] Boerma WG. Profiles of general practice in Europe. An international study of variation in the tasks of general practitioners. Nivel, Utrecht, 2003. Available from: https://www.nivel.nl/ sites/default/files/bestanden/profiles-of-general-practice-ineurope.pdf [accessed: April 16, 2019].

[6] Masseria C, Irwin R, Thomson S, et al. Primary care in Europe. European Commission Directorate-General "Employment, Social Affairs And Equal Opportunities" Unit El - Social and Demographic Analysis. Available from: http://www.ec.europa.eu/ social/BlobServlet?docId=4739\&langId=en [accessed: February 12,2018$]$.

[7] Belecz B, Paulik E, Balogh S, et al. Health status of women in southern great plain. [A nők egészségi állapota és egészségmagatartása dél-alföldi megyékben.] Medicus Universalis 2004; 37: 171-176. [Hungarian]

[8] Gress S, Delnij DM, Groenewegen PP. Managing primary care behaviour through payment systems and financial incentives. In: Saltman RB, Rico A, Boerma WG. (eds.) Primary care in the driver's seat? Organizational reform in European primary care. Open University Press, Maidenhead, 2006; pp. 184-200.

[9] Payment system of PHC. [Az alapellátási rendszerek finanszírozása. In: Az alapellátás jellemzői Európában.] Gyógyszerészeti és Egészségügyi Minőség- és Szervezetfejlesztési Intézet (GYEMSZI), Informatikai és Rendszerelemzési Főigazgatóság, Budapest, 2014; pp. 11-20. [Hungarian]

[10] Gress S, Focke A, Hessel F, et al. Financial incentives for disease management programmes and integrated care in German social health insurance. Health Policy 2006, 78: 295-305.

[11] Kringos DS, Boerma WG, Hutchinson A, et al. The breadth of primary care: a systematic literature review of its core dimensions. BMC Health Serv Res. 2010; 10: 65.
[12] Belec B, Paulik E, Balogh S, et al. The effect of schooling on health status in Csongrád County. [Az iskolázottság hatása az egészségi állapotra Csongrád megyében.] Medicus Universalis 2004; 37: 11-16. [Hungarian]

[13] Nédó E, Paulik E. Association of smoking, physical activity, and dietary habits with socioeconomic variables: a cross-sectional study in adults on both sides of the Hungarian-Romanian border. BMC Public Health 2012; 12: 60.

[14] Paulik E, Nagymajtényi L, Easterling D, et al. Smoking behaviour and attitudes of Hungarian Roma and non-Roma population towards tobacco control policies. Int J Public Health 2011; 56: 485-491.

[15] Balogh S, Papp R, Józan P, et al. Continued improvement of cardiovascular mortality in Hungary - impact of increased cardio-metabolic prescriptions. BMC Public Health 2010; 10: 422.

[16] Balogh S. Praxisanalysis in GP praxises and one possible method. [A körzeti munka elemzése és egy lehetséges módszere.] Medicus Universalis 1986; 19: 213-217. [Hungarian]

[17] Balogh S, Arnold Cs, Diós E, et al. Comparative examination of the curative-preventive activity of district doctors in 6 districts. [A körzeti orvosok gyógyító-megelőző tevékenységének összehasonlító vizsgálata hat körzetben.] Medicus Universalis 1987; 20: 337-341. [Hungarian]

[18] Balogh S. Comparative evaluation of seven practices. [Hét körzeti praxis összehasonlító értékelése.] Medicus Universalis 1990; 23: 335-340. [Hungarian]

[19] Paulik E, Balogh S, Belec B, et al. Epidemiological characteristics of obesity in the Southern Great Plain. [Az elhízás epidemiológiai jellemzői a Dél-Alföldön.] Népegészségügy 2004; 83: 1217. [Hungarian]

[20] Balogh S. Family medicine in the mirror of social security data I. First months of departure. [A háziorvoslás a társadalombiztosítási adatok tükrében I. Az indulás első hónapjai.] Medicus Universalis 1995; 28: 195-200. [Hungarian]

[21] Balogh S. Micro-regional cooperation, such as the possibility of structural change and the identity of public health issues. [A kistérségi együttmúködés, mint a struktúraváltás lehetősége és a népegészségügyi kérdések azonossága.] Medicus Universalis 2007; 40: 99-101. [Hungarian]

[22] Hargitai R, Balogh S. Micro-regional cooperation, such as the possibility of structural change and the identity of public health issues. [Kistérségi Egészségközpont - Az alapellátási struktúraváltoztatás lehetséges modellje.] Medicus Universalis 2007; 40: 9-13. [Hungarian]

[23] Balogh S, Hajnal F. A model, by making common task force out of scientific organisation, the academic sector and governmental institute was realised in Hungary to support the specific family physician training, and to implement research and development projects in the primary healthcare. Part I. [Tudományos szakmai szervezet, az akadémiai szektor és országos intézet összefogásának modellje a családorvos-szakképzés, az alapellátás kutatás-fejlesztés színterein. I. rész] Orv Hetil. 2018; 159: 13101316.

(Balogh Sándor dr., Budapest, Görgey u. 40., 1041 e-mail: balogh.sandor@pte.hu)

A cikk a Creative Commons Attribution 4.0 International License (https://creativecommons.org/licenses/by/4.0/) feltételei szerint publikált Open Access közlemény, melynek szellemében a cikk bármilyen médiumban szabadon felhasználható, megosztható és újraközölhető, feltéve, hogy az eredeti szerző és a közlés helye, illetve a CC License linkje és az esetlegesen végrehajtott módosítások feltüntetésre kerülnek. (SID_1) 